\title{
ASAL-USUL TEOLOGI: PELACAKAN HISTORIS FILOSOFIS
}

\author{
Cecep Zakarias E1 Bilad \\ Institut Agama Islam Negeri Palangka Raya \\ cecepelbilad@iain-palangkaraya.ac.id \\ Diterima 12 April 2018 | Direview 27 Agustus 2018| Diterbitkan 01 Oktober 2018
}

\begin{abstract}
:
This study attempts to examine the origin of theology. In every religion, it is the most substantial element, because it is the intellectual discourse around the divinity and belief of that religion. We know the terms such as Christian Theology, Jewish Theology, Islamic Theology, Hindu Theology and so on. From here, howeover, it raises the question of what theology is intrinsically? Etymologically the term theology is in fact derived from the Greek whose people are the worshipers of the gods and do not recognize the conception of divinity as other religions do. How can it exist in these religions? From this historical-philosophical search it is found that theology in its generic meaning is defined as the discourse of the exalted supranatural being. It is born naturally in every society from time to time. It can take a variety of forms according to the religious tradition of its people, but in essence it is the discourse on the One who organizes and manages the universe.
\end{abstract}

Keywords: Theology; Religion; Supranatural being; Polytheism; Monotheism.

\begin{abstract}
Abstrak:
Penelitian ini mencoba untuk. menguji asal-usul teologi. Dalam setiap agama, itu adalab elemen yang paling penting, karena itu adalab wacana intelektual di sekitar keilabian dan keyakinan agama itu. Kami tahu istilah-istilah seperti Teologi Kristen, Teologi Yabudi, Teologi Islam, Teologi Hindu, dan sebagainya. Dari sini, bagaimanapun, itu menimbulkan pertanyaan tentang apa teologi secara intrinsik? Secara etimologis, istilah teologi sebenarnya berasal dari bahasa Yunani yang orang-orangnya adalah penyembah dewa-dewa dan tidak mengakui konsepsi ketuhanan sebagaimana agama-agama lain lakukan. Bagaimana bisa ada dalam agama-agama ini? Dari pencarian historis-filosofis ini ditemukan bahwa teologi dalam arti generiknya didefinisikan sebagai wacana wujud supranatural yang agung. Ia labir secara alami di setiap masyarakat dari waktu ke waktu. Ini bisa mengambil berbagai bentuk sesuai dengan tradisi agama rakyatnya, tetapi pada dasarnya itu adalah wacana tentang Dia yang mengatur dan mengatur alam semesta.
\end{abstract}

Kata Kunci: Teologi, Agama, Supra Natural, Politeisme, Monoteisme.

\section{Pendahuluan}

Teologi adalah istilah yang sudah populer dalam kajian agama-agama. Dalam Islam, istilah ini (Teologi Islam) disepadankan maksudnya dengan Ilmu Kalam atau Ilmu Ushuluddin, yakni ilmu yang berbicara seputar keimanan kepada Allah SWT. Namun bagi sebagian orang, teologi sering diidentikkan dengan agama Nasrani, karena istilah tersebut memang paling sering terdengar dari kalangan mereka. Hal ini bisa dimaklumi karena sebagaimana akan dibahas, kalangan gereja di Eropa lah yang pertama kali mempopulerkan kata tersebut di khalayak jamaahnya. Meskipun sebenarnya, selain Nasrani dan Islam, umat Yahudi juga mengenal istilah tersebut yakni istilah Teologi Yahudi (Jewish Theology). Ini berarti bahwa teologi sebenarnya adalah istilah bersama, tidak milik satu agama tertentu.

Tiga agama samawi tersebut basisnya adalah keyakinan akan adanya Tuhan pencipta alam. Di masing-masing agama tersebut, teologi berperan sebagai kajian rasional tentang hal ihwal wujud yang disembah itu. Inilah mengapa teologi merupakan bidang prinsip dalam tradisi intelektual Kristen, Yahudi maupun Islam. Di awal pertumbuhannya sekitar abad $2 \mathrm{H}$, teologi Islam tampil sebagai benteng rasional bagi aqidah umat Islam. Ketika persebaran Islam menembus batas-batas jaziarah Arab ke berbagai penjuru peradaban, dialog dan debat seputar basis rasional keimanan umat Islam tak bisa dielakkan. Pada saat itu, para ulama pakar teologi tampil terdepan menghadapi para pendebatnya. Demikian pentingnya peran dari ilmu yang juga disebut Ilmu Kalam ini, khususnya dalam konteks menghadapi para 
pendebat non-Muslim itu, membuat Imam Nawawi dan sebagian ulama lainnya menghukumi wajib untuk belajar Ilmu Kalam bagi setiap Muslim. ${ }^{1}$

Teologi, dalam Kamus Besar Bahasa Indonesia, berarti pengetahuan ketuhanan (mengenai sifat Allah, dasar kepercayaan kepada Allah dan agama, terutama berdasar pada kitab suci). ${ }^{2}$ Kata tersebut diderivasi dari kata bahasa Inggris theology, yang juga diserap dari kata Bahasa Perancis théologie, dari Bahasa Latin theologia, dan berakar dari Bahasa Yunani theologia. ${ }^{3}$ Dalam Oxford Dictionaries, theology berarti the study of the nature of God and religious belief (studi tentang ketuhanan dan keimanan dalam agama). ${ }^{4}$

Pada perkembangannya, muncul istilah Budhis Theology (Teologi Budha) di kalangan umat Budha dan Hindu Theology (Teologi Hindu) di kalangan umat Hindu. Seperti halnya di tiga agama Abrahamik, teologi Budha dan teologi Hindu tentu merupakan kajian rasional seputar konsepsi ketuhanan dalam perspektif ajarannya masing-masing. Sampai di sini, ternyata teologi dapat diklaim oleh setiap agama bahkan mungkin juga agama-agama lokal semisal Kaharingan di Kalimantan Tengah, Sunda Wiwitan di Banten dan Jawa Barat, Kejawen di Jawa Tengah dan Timur, dan lain sebagainya di berbagai pelosok dunia. Saat ini, bahkan teologi menjadi istilah yang sangat lentur. Dalam diskursus pemikiran agama kontemporer, dikenal istilah misalkan Teologi Pembebasan (Liberation Theology) dan Teologi Lingkungan (Ecological/Green Theology), Teologi Bencana, Teologi Feminisme/Gender, dan lain sebagainya. Pemasangan ini berbasis pada isu, di mana teologi suatu agama digunakan sebagai perspektif untuk mendeskripsikan, menjelaskan atau mencari solusi atas suatu topik persoalan.

Fakta tersebut menunjukkan bahwa teologi adalah istilah lintas agama. Ini meluruskan pandangan umum yang mengidentikkan teologi dengan agama Nasrani. Padahal secara etimologis, istilah teologi bisa dilacak hingga peradaban Yunani di era kejayaannya sekitar abad ke 6-3 SM. Kata teologi adalah gabungan dari dua kata Bahasa Yunani, theos yang sering diartikan Tuhan dan logos yang diartikan ilmu. Jadi teologi berarti ilmu seputar ketuhanan. Ini berarti usia kata tersebut jauh lebih tua dari agama Nasrani itu sendiri yang baru lahir di abad pertama masehi. Istilah ini pertama kali diperkenalkan oleh Aristoteles (384-322 SM) dalam karyanya Metaphysics. Aristoteles sendiri terinspirasi dari gurunya Plato (427-347 SM), sebagai orang pertama yang menciptakan kata 'teolog' (theologian).

Dari sini dapat dilihat hubungan erat antara teologi dan filsafat, dan teologi tidak memiliki hubungan apapun dengan agama tertentu. Kalaupun ada, hubungan tersebut justru dengan tradisi politeisme yang saat itu dianut masyarakat Yunani tempat istilah teologi dilahirkan. Ini berarti bahwa hubungan teologi dan agama yang berlangsung hingga saat ini, sehingga penyebutannya selalu disematkan dengan agama tertentu seperti Teologi Kristen, Teologi Islam dan Teologi Yahudi, memiliki alur historisnya tersendiri. Ada jarak historis yang membentang antara masa keemasan Peradaban Yunani dari abad 6-4 SM dengan peradaban Kristen yang mulai tumbuh pada abad ke-1 M. Selain itu, antara teologi dan agama juga terpisahkan jurang epistemologis yang dalam. Di awal pertumbuhannya di Yunani, teologi sebagai bagian integral dari filsafat berkarakter rasional, sedangkan agama berkarakter irasional, berbasis pada wahyu. Oleh karena itu, ketika teologi merasuk ke dalam

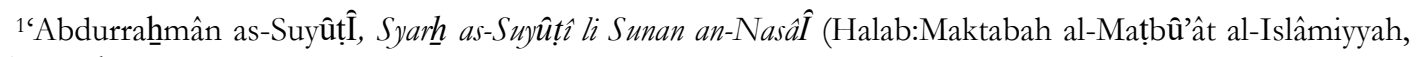
1986), juz. 3, h. 189

${ }^{2}$ Pusat Bahasa Pendidikan Nasional, Kamus Bahasa Indonesia (Pusat Bahasa: Jakarta, 2008), h. 1683

3https://www.merriam-webster.com/dictionary/theology;

https://en.oxforddictionaries.com/definition/theology, diakses pada 26 September 2017, pukul 09.05

${ }^{4}$ https://en.oxforddictionaries.com/definition/theology, diakses 31 Juli 2017, pukul. 14.05.

${ }^{5}$ Edward Caird, the Evolution of Theology in the Greek Philosophers (Oregon: Wift \& Stock Publishers, 2015), Vol. 1, h. 31 
agama Kristen, Islam atau agama apapun, di situ pasti ada pergeseran epistemologis dalam diri teologi itu sendiri.

Artikel ini akan menelusuri konteks historis-filosofis di sekitar kelahiran dan perkembangan teologi. Di bagian-bagian tertentu, penulis juga akan secara kritis merefleksikannya dalam konteks keagamaan masa kini.

\section{Redefinisi Teologi}

Dari uraian sepintas di atas, teologi ternyata telah melewati sejumlah fase sejarah dan peradaban dalam rentang waktu yang sangat panjang. Lahir di Yunani pada abad ke-6 SM dan berkembang di berbagai peradaban agama. Dalam rentang waktu yang panjang tersebut, makna dan pemahaman orang tentang istilah teologi tentunya juga mengalami banyak pergeseran. Saat ini, kata theos sering diartikan sebagai tuhan dan logos diartikan sebagai ilmu. Dari pengertian ini kemudian lahirlah definisi teologi yang sering kita dengar, yakni ilmu tentang ketuhanan; ilmu seputar seluk-beluk Tuhan. Dalam Kamus Besar Bahasa Indonesia, definisi teologi berbunyi "pengetahuan ketuhanan (mengenai sifat Allah, dasar kepercayaan kepada Allah dan agama, terutama berdasar pada kitab suci)." Padahal, terma theologian ketika pertama kali diciptakan Plato di Yunani adalah dalam konteks lingkungan masyarakat yang politeis, percaya dan menyembah dewa-dewa. ${ }^{7}$ Oleh sebab itu, kata theos tentunya dipahami dalam makna sekitar hal ihwal para dewa. Mereka tidak pernah mengenal konsep Tuhan Esa sebagaimana yang dimiliki oleh masyarakat penganut agama monoteis. Maka dari itu definisi teologi sebagai ilmu seputar ketuhanan (dalam makna Tuhan sebagaimana dipahami oleh umat monoteis) hanya dapat berlaku secara eksklusif di kalangan masyarakat monoteis, dan mengekslusi kaum politeis yang tidak mengenal konsep Tuhan semisal masyarakat Yunani sendiri selaku pencipta kata tersebut. Sementara itu Plato sendiri saat menjabarkan gagasan-gagasan teologisnya, mengikuti konteks masyarakatnya tersebut. Ia berbicara tentang para dewa (gods), tentang peran dan tugas mereka dalam mengatur sistem alam semesta. Plato juga merumuskan kaidah-kaidah tentang bagaimana seharusnya kisahkisah para dewa itu disampaikan kepada masyarakat. ${ }^{8}$

Oleh sebab itu, perlu dirumuskan definisi teologi yang lebih luas agar dapat melingkupi semua tradisi relijius baik yang monoteis maupun politeis. Upaya ini bisa dimulai dengan menelusuri akar etimologisnya, yaitu kata theos. Dalam memaparkan gagasan teologisnya, Plato berbicara di seputar kepercayaan masyarakat Yunani tentang keberadaan para dewa. Di situ ia bermaksud menawarkan sebuah gagasan baru, bahwa berdasarkan investigasi filosofis alam semesta ini bermula dari suatu wujud yang Esa, yang Abadi. Wujud yang merupakan Sebab Puncak (an ultimate efficient cause) dari semesta rangkaian kausalitas. Wujud yang juga merupakan pencipta para dewa. ${ }^{9}$ Plato memberinya nama khusus yaitu démiourgos (the Demiurge) yang berarti pembuat; pencipta. Pembicaraan Plato tentang hal-ihwal para dewa tersebut dan gagasannya tentang demiourgos, oleh muridnya Aristoteles disebut dengan teologi. Aristoteles kemudian mengembangkannya lebih jauh dalam karyanya yang berjudul Metafisika (the Metaphysics). Ini berarti bahwa, makna kata theos sebenarnya tidak identik dengan tuhan dalam tradisi agama-agama monoteis, tidak pula dengan istilah dewa dalam

${ }^{6}$ Kamus Bahasa Indonesia (Jakarta: Pusat Bahasa Departemen Pendidikan Nasional, 2008) h. 1683.

${ }^{7}$ Sementara Aristoteles membuat istilah "teologi” sebagai nama lain dari metafisika atau first philosophy, sehingga teologi merupakan bagian integral bahkan inti dari filsafat itu sendiri. Ini akan dibahas lebih lanjut di sub-bab berikutnya.

${ }^{8}$ Michael Bordt, "typoi peri theologias and the Knowledge of the Good," dalam Karl-und-Gertrud-Abel Stiftung, Ideal and Culture of Knowledge in Plato (Frankfurt: Franz Steiner Verlag Stuttgart, 2003), h. 72

${ }^{9}$ Michael Bordt, "typoi peri theologias and the Knowledge of the Good," hal. 72; Hugh H. Benson (Ed.), A Companion to Plato (Oxford: Blackwell Publishing, 2006) h. 253 
tradisi politeis. Namun apa yang dimaksudkan tuhan (the God) dan dewa (gods atau deities), keduanya tercakup di dalam makna kata theos.

Dengan demikian, padanan kata yang lebih komprehensif untuk kata theos adalah the divine, yang berarti sesuatu atau sosok yang agung, sakral, suci, bagaimanapun sesuatu atau sosok tersebut dinamakan dan dikonsepsikan. Dari sini, bisa kita lakukan pendefinisian yang komprehensif untuk kata teologi. Robert Jackson, misalnya, mendefinisikan teologi, "to discouse about the divine" (diskursus tentang wujud yang diagungkan). ${ }^{10}$ Definisi lain yang juga komprehensif misalkan menurut Richard Hooker, yaitu: "ilmu tentang segala sesuatu yang diagungkan (the science of things divine)." 11 Dengan definisi ini, maka teologi dapat mencakup semua jenis diskursus tentang wujud-wujud yang disakralkan dan dalam komunitas relijius apapun baik yang monoteis maupun politeis.

Setiap agama tentu mengajarkan bahwa alam semesta tidak mengada begitu saja, tetapi ada yang mengadakan/menciptakan. Sistem kehidupan di dalamnya pun tidak berlangsung begitu saja, tetapi pasti ada yang mengendalikan dan mengaturnya. Namun demikian, agamaagama itu memiliki konsepsinya masing-masing tentang wujud pencipta alam semesta tersebut. Ada yang mengkonsepsikannya dengan Tuhan yang Maha Tunggal (the One God), yang dikenal dengan nama Allah dalam Islam, Yahweh atau Adonai dalam Yahudi, Jehovah dalam Kristen Protestan, dan lain sebagainya; ada pula yang mengkonsepsikannya dengan banyak tuhan (the gods/deities), misalnya dalam agama-agama kuno Yunani, Romawi, Mesir, Sumeria, dan lain sebagainya.

Menurut David Tracy, dengan makna yang mendasar seperti ini, teologi dapat mencakup setiap diskursus intelektual seputar hal-ihwal ketuhanan dalam semua tradisi agama. Bahkan dalam tradisi nonteistik sekalipun yang tidak secara spesifik memiliki konsep penciptaan, ${ }^{12}$ misalnya Hindu, Budha, Konfusianisme, Taoisme dan tradisi-tradisi agama kuno, bisa dikatakan mereka juga memiliki teologi. Lebih jauh Tracy berpendapat, bahwa teologi tidak mensyaratkan adanya suatu konsep tertentu tentang tuhan dan yang diberikan nama tertentu misalkan Allah atau Jehovah. Selama sebuah tradisi relijius memiliki gagasan tentang adanya the ultimate reality (Realitas Tertinggi), apapun itu sebutannya, dan selama refleksi intelektual tentang Realitas Tertinggi itu masih berlangsung, maka di situlah kita temukan hadirnya teologi. ${ }^{13}$

Dalam makna yang luas ini, teologi jelas jauh lebih tua dari Yunani itu sendiri. Secara etimologis kata teologi memang lahir di Yunani, tapi secara substantif sebagai diskursus intelektual seputar the ultimate reality teologi sudah eksis jauh sebelum itu dalam setiap tradisi relijius. Dengan kata lain, teologi sudah setua umur peradaban umat manusia itu sendiri, karena dari zaman ke zaman setiap masyarakat pasti memiliki tradisi relijiusitas. Tradisi tersebut muncul dari potensi alamiah yang dimiliki manusia, yaitu akal-pikiran. Dengan kemampuan akalnya itu, manusia terdorong untuk menelisik tentang segala hal di sekelilingnya, termasuk meneliti tentang dari mana dan bagaimana alam semesta ini terwujud, serta siapa yang mewujudkannya. Diskursus pun terbentuk di antara mereka tentang hal-ihwal alam semesta, yang akhirnya melahirkan tradisi relijius dengan berbagai keyakinan, ajaran dan ritualnya. Demikianlah asal-muasal terbentuknya tradisi-tradisi keagamaan di setiap masyarakat dalam sejarah umat manusia.

${ }^{10}$ Roger R. Jackson, Buddhist Theology: Critical Reflections by Contemporary Buddhist Scholars (Surrey: Curzon Press, 2000), h. 1

${ }^{11}$ Richard Hooker, Of the Laws of Ecclesiastical Polity

${ }^{12}$ Jackson, Op.cit., h. 1

${ }^{13} \mathrm{Ibid}$. 


\section{Asal-Usul Agama}

Agama atau kepercayaan adalah fenomena yang niscaya pada setiap kelompok masyarakat. Dalam bentuknya masing-masing, setiap masyarakat memiliki tradisi keyakinan dan peribadatan. Para sosiolog meyakini, fenomena tersebut lahir secara alami yang bersumber dari potensi relijiusitas yang secara alami sudah tertanam dalam diri setiap orang. Manusia terlahir dengan membawa segudang potensi dan bakat, satu di antaranya adalah relijiusitas. Oleh karenanya manusia dijuluki religious animal (binatang yang relijius). Dalam khasanah intelektual Islam, agama diyakini sebagai fitrah manusia. Kepercayaan ini berbasis pada sejumlah ayat dan hadits yang mengabarkan tentang adanya benih tauhid dalam diri setiap manusia. Misalnya, dalam QS. Ar-Rum: 30:

"Maka hadapkanlah wajahmu secara lurus kepada ad-dîn, sebagai fitrah dari Allah dan manusia diciptakan berdasarkan fitrah tersebut."

Sebuah hadits Nabi juga mengatakan:

"Setiap manusia dilabirkan dalam fitrah. Kedua orangtuanya lab yang menjadikannya yabudi, nasrani atau majusi' (HR.Muttafaqun 'alaîh).

Masyarakat adalah kumpulan manusia, sehingga jika agama adalah fitrah manusia maka agama pun juga adalah fitrah sebuah masyarakat. Tradisi relijiusitas akan selalu lahir dalam setiap kelompok masyarakat. Mengenai hal ini ada sebuah isyarat dalam al-Quran, "dan pada setiap kaum/umat di sana pasti ada seorang Rasul..." (QS. Yunus, 47). Kendati demikian, tidak ada yang tahu pasti agama apakah yang dianut umat manusia pertama kali. Secara historis, sejumlah agama yang hingga hari ini eksis sudah berumur ribuan tahun, misalnya Hindu, Zoroaster, Yahudi (Nabi Musa di 1200an SM). Disusul dengan Nasrani di permulaan tahun Masehi, lalu Islam dan Budha di paruh kedua millennium pertama. Di luar itu, masih ada banyak lagi komunitas agama yang bersifat lokal, dianut oleh komunitas di daerah tertentu dan tidak menyebar ke berbagai penjuru dunia, misalnya Sunda Wiwitan di Banten dan Jawa Barat, Kaharingan di Kalimantan Tengah. Selain agama-agama itu, tentunya masih banyak lagi agama yang pernah dianut umat manusia yang hari ini tidak lagi eksis dan tidak pula terlacak oleh para sejarawan.

Berdasarkan agama-agama yang saat ini masih eksis, para pakar menganalisa bahwa ada sejumlah unsur yang selalu ada pada setiap agama. Prof. Burhanuddin Agus, misalnya, mengidentifikasi lima unsur agama yaitu kepercayaan kepada kekuatan gaib, aspek sakral, aspek ritual, penganut, dan mistisisme. ${ }^{14}$ Pertama, setiap agama pasti mengajarkan tentang adanya wujud-wujud supranatural yang memiliki peran tertentu dalam pengelolaan kehidupan. Di sinilah muncul konsepsi Tuhan sebagai wujud supranatural yang tertinggi (the ultimate reality), dan konsepsi tentang mahluk-mahluk nonfisik seperti jin, setan, malaikat dan lain-lain. Kedua, dalam sebuah agama pasti ada praktek sakralisasi sosok atau benda-benda tertentu yang memiliki kaitan dengan wujud atau kekuatan supranatural. Disakralkan dalam arti ditinggikan atau diagungkan posisinya. Di Islam sendiri, misalnya, benda-benda yang disakralkan seperti Ka'bah, Masjid, mushaf al-Quran, makam para wali; sosok yang disakralkan misalnya Nabi SAW, para Sahabat dan para waliyullah. Ketiga, setiap agama pasti memiliki praktek-praktek ritual sebagai wujud persembahan kepada the ultimate reality yang dipercayai. Dalam Islam, misalnya ada shalat, puasa, zakat, haji, akad nikah, dan

${ }^{14}$ Burhanuddin Agus, Agama Dalam Kehidupan Manusia: Pengantar Anthropologi Agama (Jakarta: Rajawali Press, 2006) 
lain-lain, sebagai ritual penyembahan kepada Allah SWT. Keempat setiap agama tentunya mempunyai penganut. Kelima, pengalaman mistis. Berhubung agama itu sebagai sarana manusia dalam berhubungan dengan Tuhan, the ultimate reality, maka praktek dan pengamalannya membuahkan kesan-kesan mistis-psikologis yang membawa kedamaian, kebahagiaan dan ketentraman. Ketika manusia harus berjuang menghadapi problematika sehari-hari, agama menawarkan kenyamanan ruhani bagi mereka. Sebab, melalui agamalah manusia dapat berkomunikasi dengan Penciptanya. Dengan lima aspeknya ini, dari zaman ke zaman agama menjadi tempat bagi manusia dalam mencari keamanan, kenyamanan, ketentraman ruhani dan keteratuan hidup.

Menurut James Weir, Jr., M.D., pada dasarnya perasaan relijius manusia muncul dari salah satu hukum alam yaitu self-protection (perlindungan diri). ${ }^{15} \mathrm{Di}$ antara kebutuhan paling dasar manusia adalah bertahan hidup. Manusia sadar bahwa dirinya adalah bagian kecil dari bentangan alam semesta, dan juga bukan satu-satunya penghuni di dalamnya. Dahulu kala, di zaman primitif, ketika kecerdasan dan keterampilan manusia masih sangat sederhana, alam semesta yang maha luas ini nampak begitu menakutkan dan terasa begitu berat untuk diarungi: hutan belantara, terik matahari, lebatnya hujan, kilatan petir, gemuruh sungai, pohon-pohon yang tinggi besar, binatang-binatang buas, dan lain sebagainya. Sementara manusia melihat dirinya, tubuh dan tenaganya, jauh lebih kecil dan lemah dibandingkan dengan itu semua. Lalu, ia pun melakukan personifikasi. Objek-objek alam itu, matahari, bulan, bintang, air terjun, pohon-pohon besar, gunung, dianggapnya sebagai person, sosoksosok lain selain dirinya yang nampak baginya lebih kuat dan dapat mengancam keselamatannya. ${ }^{16}$

Dari personifikasi ini, manusia kemudian merumuskan bagaimana ia harus bersikap. Menurut Weir, pada kondisi yang masih demikian, kualitas manusia hanya satu derajat di atas binatang. ${ }^{17}$ Seperti seekor anjing di hadapan manusia. Pada taraf tertentu, anjing sadar bahwa manusia (tuannya) adalah sosok selain dirinya, yang memiliki power lebih besar yang mungkin bisa berbahaya bagi dirinya. Untuk itu, anjing berusaha mengambil hati tuannya agar tidak berniat buruk kepadanya. Inilah pola beragama manusia primitif. Objek-objek alam itu dipersonifikasi sebagai sosok lain di luar dirinya yang berkekuatan dan mungkin berbahaya. Maka manusia menjadikannya sasaran pemujaan, dengan maksud mengambil hati (propitiation) agar mereka tidak berniat buruk kepadanya. Di sisi lain, pemujaan semacam ini bukanlah wujud pemujaan yang sesungguhnya. ${ }^{18}$ Mereka melakukan ritual-ritual bukan berbasis pada suatu kesadaran intelektual-spiritual - karena memang belum mencapai taraf itu - tetapi masih karena dorongan materialis untuk bertahan hidup, mencari keselamatan dan keamanan. Mereka menyembah pohon, gunung, matahari, binatang tertentu, gua, batu besar - kepercayaan-kepercayaan yang di kemudian hari dikenal dengan animisme.

Seiring waktu, keterampilan dan intelektualitas manusia terus berkembang. Mereka semakin berpengalaman dan lihai menghadapi problem-problem survival. Kehidupannya sudah tidak lagi berpindah-pindah untuk bertahan hidup. Mereka

15James Weir, Jr., M.D, Religion and Lust or The Psychical Correlation of Religious Emmotion and Sexual Desire: Thrid Edition (Chicago: Chicago Medical Book Co., 1905), h. 13.

16Weir, h. 5.

${ }^{17}$ Weir, h. 13.

18Weir, h. 5. 
sudah mulai menetap, bercocok tanam, berdagang. Mereka sudah bisa berdamai dengan alam, dan kehidupan menjadi terasa lebih mudah. Mereka sudah mampu mengelola alam sebagaimana mestinya untuk mencukupi kebutuhan hidup. Di sisi lain, mereka semakin punya kesempatan untuk berpikir, merenung lebih dalam tentang alam semesta. Nalarnya semakin berkembang dan semakin lihai berpikir abstrak dan konseptual. Dengan itu, mereka mulai bisa merancang konsep-konsep dan strategi untuk menyelesaikan problematika sehari-hari; menciptakan perangkatperangkat teknologi untuk mempermudah urusan sehari-hari. Perkembangan ini berlanjut dari waktu ke waktu, dari yang paling sederhana hingga modern seperti sekarang ini.

Seiring dengan itu, di ranah relijiusitas mereka sudah mulai menangkap adanya keteraturan di alam semesta. Objek-objek yang selama ini diyakini hidup, berkekuatan dan berbahaya itu, misalnya matahari, gunung, pohon besar dan petir, ternyata hanya bagian dari hamparan sistem alam semesta. Dari hasil perenungannya, mereka mulai menangkap adanya wujud-wujud lain di alam semesta yang tersembunyi dari jangkauan mata. Wujud-wujud supranatural itu begitu tangguh mampu mengelola dan mengendalikan fenomena-fenomena alam semesta. Di situlah mulai tercipta konsepkonsep tentang hantu, setan, arwah, dewa-dewa, dan yang semacamnya. Dirancanglah pula konsep-konsep pemujaan, penyembahan serta mitos-mitos terkait dengan wujud-wujud supranatural tersebut. Demikianlah seterusnya pola-pola dan karakter relijiusitas manusia berkembang dari waktu ke waktu.

Ketika umat manusia mencapai taraf lanjut dalam perkembangan intelektual, pola keberagamaan monoteistik yang percaya akan adanya pencipta tunggal mulai muncul. Contohnya adalah pada peradaban Yunani, seperti sudah disinggung sebelumnya. Semula, masyarakat Yunani adalah para pemuja dewa-dewa. Kepercayaan relijius mereka terbangun dari hasil perenungan para pemikirnya - dua di antaranya yang paling terkenal adalah Hesiod dan Homer. Hasil perenungan mereka dituangkan dalam karya-karya sastra yang memuat kisah-kisah legendaris nan mistis seputar para dewa, seperti Zeus, Poseidon, Hera, Demeter, Athena, Ares, Aphrodite, Apollo, Artemis, Hephaetus, Hermes, dan lain-lain Melalui karya-karya mereka, keyakinan mistik, ritual dan tradisi keberagamaan Bangsa Yunani kuno terbangun. Seiring dengan perkembangan zaman, di Yunani itu muncul kaum filsuf, di antaranya adalah Plato. Ia merintis sebuah konsepsi tentang adanya wujud puncak, tunggal, the ultimate being, yang dinamakannya demiourgos, sebagai wujud yang melampaui para dewa, yang menjadi sumber wujud bagi alam semesta. Meskipun bersifat rasional dan hanya populer di kalangan para filsufnya, dengan gagasanya yang bernuansa monoteistik itu Plato mewakili sebuah masyarakat (Yunani) politeistik yang bergerak ke arah monoteistik.

\section{Dari Agama ke Teologi}

Uraian tersebut di atas menggambarkan bagaimana manusia, secara mandiri mengenal dan memahami alam semesta, mencari siapa pengelola dan penciptanya. Gambaran tersebut paling tidak menjadi potret bagi proses serupa yang terjadi di berbagai belahan bumi lainnya. Maka di buku-buku sejarah kita bisa temukan tradisitradisi keberagamaan di berbagai belahan bumi, baik yang animisme, dinamisme, politeisme maupun monoteisme. 
Namun demikian, tidak semua tradisi keberagamaan terbangun secara alami dan mandiri. Yang paling banyak pengikutnya dan bertahan hingga kini adalah justru tradisi-tradisi relijius yang terlahir dari anugerah ilahi. Dalam arti, sebuah masyarakat yang semula sudah mempunyai tradisi relijius tertentu kemudian memperoleh kabar ilahi atau wahyu dari Tuhan Sang Pencipta. Dengan wahyu tersebut, melalui seorang rasul-Nya, Sang Pencipta memperkenalkan diri-Nya sekaligus memberi petunjuk hidup juga tatacara pemujaan kepada-Nya. Ketika wahyu tersebut diterima dan diamalkan, terbentuklah tradisi relijius baru yang berbasis pada kabar ilahi tersebut, menggantikan tradisi sebelumnya yang berbasis pada perenungan intelektual nenek moyang.

Di nusantara sendiri misalnya, semula masyarakatnya adalah para penganut animisme-dinamisme sebagai tradisi relijius yang terbangun secara alami dan mandiri. Setelah terjadi kontak budaya dengan berbagai suku-bangsa lain, tradisi relijiius masyarakat nusantara pun berevolusi, menjadi Hindu dan Budha. Setelah sekian ratus tahun berlalu, Islam masuk dan kemudian disusul Nasrani. Kini, tinggal sedikit masyarakat nusantara yang masih memeluk tradisi relijius alami itu. Hanya di lokallokal tertentu, misalnya Sunda Wiwitan di Banten dan Jawa Barat, Kaharingan di Kalimantan Tengah. Secara sadar kebanyakan masyarakat nusantara sudah beralih menganut agama-agama wahyu, yaitu Islam sebagai yang terbesar, disusul oleh Nasrani, Hindu, Budha dan Konghucu. ${ }^{19}$

Dari sisi konsepsi ketuhanannya, agama-agama tersebut bisa dikelompokkan menjadi dua, politeisme dan monoteisme.

a. Politeisme, yaitu kelompok tradisi relijius yang terbangun dari keyakinian pada banyak tuhan. ${ }^{20}$ Mereka meyakini bahwa di balik alam semesta ada sejumlah wujud supranatural, yang dengan kekuatannya wujud-wujud tersebut mengelola alam semesta. Namun dalam lingkungan politeis ini, ada juga yang percaya adanya Pencipta yang Maha Tunggal, yang kemudian bermanifestasi ke dalam sejumlah wujud suptranatural. Jadi, ada semacam hirarki ketuhanan dari yang tertinggi yakni Sang Pencipta dan tuhan-tuhan lainnya. Prosesi peribadatan kemudian dirancang berdasarkan jenjang-jenjang ilahiah tersebut.

Sebagai contoh agama Hindu. Terlepas dari adanya keragaman sekte di dalamnya dengan konsepsinya masing-masing tentang para dewa serta ajaran-ajaran dan praktek peribadatannya, mereka sama-sama meyakini adanya the supreme being (Wujud Tertinggi) yang merupakan sumber dari semua eksistensi. ${ }^{21}$ Namun, dalam Hindu kemudian ada konsep trimurti bahwa Wujud Tertinggi tersebut

${ }^{19}$ Dr. H.M. Rashidi dalam buku Empat Kuliah Agama Islam Untuk Perguruan Tinggi, membuat dua klasifikasi agama, agama langit dan agama bumi. Agama langit berdasarkan wahyu, yakni Yahudi, Nasrani dan Islam, sedangkan agama bumi adalah hasil pikiran manusia semata, misalkan Hindu dan Budha. Klasifikasi ini kemudian menjadi popular melalui buku-buku pelajaran agama di sekolah. Namun,sejumlah pakar mempersoalkan klasifikasi ini, terutama dari kalangan Hindu dan Budha. Mereka tidak terima jika agamanya dimasukkan dalam rumpun agama bumi (alami). Mereka punya argumentasi tersendiri bahwa agamanya juga berbasis wahyu ilahi. Lihat misalnya, Laksmi Narayana dan Rama Putra Iswara, Mendebat Agama Langit: Membunub Dikotomi Ngawur Agama Langit-Agama Bumi (Yogyakarta: Narayana Mmrti Press, 2017).

${ }^{20}$ Simon Blackburn, the Oxford Dictionary of Philosophy (Oxford: Oxford University Press, 1996), h. 292

${ }^{21}$ Kristin Johnston Largen, Finding God among Our Neighbors: An Interfaith Systematic Theology (Fortress Press,U.S., 2017), h. 16, 23-24. 
bermanifestasi ke dalam tiga sosok suci yaitu Brahma sebagai Sang Pencipta, Siwa sebagai Sang Penghancur, dan Wisnu sebagai Sang Pemelihara. Tuhan yang Maha Satu yang tampil dalam tiga wajah. ${ }^{22}$ Masing-masing perwujudan ilahiah tersebut lalu divisualkan dalam bentuk patung-patung. Dari situ lahirlah bentukbentuk penyembahan untuk masing-masing manifestasi ilahiah tersebut.

b. Monoteisme, yaitu kelompok agama dengan keyakinan dasar pada satu tuhan. ${ }^{23}$

Mereka meyakini bahwa alam semesta dengan segala sistem kehidupannya tidak mengada dengan sendirinya, tetapi ada subjek yang menciptakan, merencanakan dan mengelolanya. Alam semesta ini sangat luas dan kompleks, maka sosok tersebut juga pastilah Maha Agung, tak ada tandingannya. Sosok tersebut secara umum dikenal dengan nama Tuhan - rabb atau ilâh dalam bahasa Arab; the God dalam bahasa Inggris. Berbeda dengan kelompok politeisme, agama-agama monoteis meyakini the ultimate being sebagai wujud yang Maha Tunggal/Esa, Mutlak, Abadi. Dalam Islam, misalnya, meskipun dalam mengelola alam semesta ini Tuhan menciptakan para malaikat, namun para malaikat itu bukanlah semacam manifestasi atau visualisasi wujud-Nya yang Esa. Mereka juga seperti halnya realitas-realitas lainnya di alam semesta, yakni sama-sama mahluk/ciptaan Allah serta sama-sama menyembah kepada-Nya. Yang patut disembah hanya Dia yang Maha Esa.

Masing-masing agama itu tentu memiliki banyak perbedaan fundamental, bahkan tak sedikit ajaran-ajarannya yang saling bertentangan. Namun ada satu hal mendasar yang mempertemukan semua agama tersebut, yaitu keyakinan bahwa alam semesta ini tidak mengada dengan sendirinya, tidak pula beroperasi dengan sendirinya, tetapi ada suatu wujud yang menciptakan dan yang mengelola - Sang Wujud Tertinggi/the ultimate being. Tentang apa/siapa wujud supranatural tersebut dinamakan dan dikonsepsikan, apakah ia tunggal ataukah jamak, di sinilah setiap agama memiliki konsepsinya masing-masing. Terlepas dari ragam perbedaan yang ada di masing-masing agama itu, keyakinan demikian hadir dalam jiwa setiap pemeluknya, secara fitrah tanpa dibuat-buat atau dipaksakan. Dengan keyakinan tersebut, maka manusia secara sukarela menganut satu agama, karena agama adalah media paling praktis untuk berkomunikasi dengan Sang Wujud Tertinggi tersebut.

Dari sini, keyakinan relijius tersebut kemudian berkembang dua arah, yakni menjadi dogma dan tradisi, dan diskursus:

Pertama, menjadi dogma dan tradisi. Saat pertama kali muncul dan tersebar, sebuah ajaran relijius diimani dan diamalkan secara sukarela dan penuh kesadaran. Kehadiran seorang rasul atau seorang bijak yang menyebarkannya kali pertama, mampu membuka cakrawala kesadaran ruhani para pengikutnya. Namun seiring dengan perkembangan zaman pencerahan ruhani serupa tidak diperoleh oleh generasi-generasi berikutnya. Ajaran itu mungkin masih eksis dan dianut hingga kini, namun itu sudah bergeser menjadi dogma. Ritual-ritualnya mungkin masih lestari hingga kini, namun itu sudah menjadi sekedar tradisi yang turun-temurun.

Islam sendiri, sebagai contoh, masih eksis hingga hari ini. Di sekolah-sekolah, madrasah, majelis taklim, ajaran-ajaran dan aturan-aturannya diajarkan. Prinsipprinsip tertentu bahkan wajib dihafalkan, misalnya Rukun Iman dan Rukun Islam. Namun ajaran-ajaran tersebut hanya sebatas diajarkan, diterima dan dihafalkan,

${ }^{22}$ Largen, h. 23-24

${ }^{23}$ Blackburn, h. 248. 
setelah itu diamalkan. Hanya sebagian kecil saja pemeluknya yang mau mengkajinya secara mendalam. Padahal pengkajian akan melahirkan pemahaman yang utuh di benak para jama'ah/anak didik. Pemahaman yang utuh akan membangkitkan kesadaran ruhani yang penuh, sehingga mereka dapat mengimani dan mengamalkannya dengan sukarela dan khusyu'.

Implikasi dari minimnya pemahaman yang mendalam adalah minimnya nilai spiritual dan nihilnya internalisasi dalam pengamalan ibadah. Haji, sebagai contoh, adalah ibadah wajib bagi umat Islam (yang mampu), seperti halnya shalat lima waktu, zakat fitrah dan puasa Ramadan. Di satu sisi, umat tahu bahwa haji adalah di antara ibadah yang wajib bagi setiap Muslim, dan ibadah adalah wujud pengabdian sukarela seorang Muslim kepada Allah. Tapi di sisi lain, haji memang juga berdimensi sosialekonomi. Secara sosial, berhubung haji adalah ibadah yang mensyaratkan kemampuan finansial, maka di sinilah haji rentan dijadikan indikator kekayaan/kelas ekonomi seseorang. Hanya orang-orang yang dari kelas ekonomi tertentu yang mampu berangkat haji. Sehingga di sini, haji rentan dianggap sebagai ibadah "eksklusif" untuk orang-orang yang secara ekonomi berkelas ekslusif pula. Oleh karenanya, di tengah konteks masyarakat yang mayoritas berkelas ekonomi menengah ke bawah, ibadah haji dapat membekaskan kebanggan tersendiri bagi siapa saja yang mampu melaksanakannya. Maka di Indonesia, terlepas dari konteks historisnya, ${ }^{24}$ untuk orang yang sudah berhaji akan diberikan gelar Haji/Hajjah di depan namanya. Dalam pergaulan sehari-hari, seperti sudah dimaklumi, orang-orang akan memanggilkannya "Pak Haji" atau "Bu Haji." Akhirnya, dengan berhaji, seseorang dapat meningkat ke kelas sosial tertentu, dengan penampilan dan sikap-sikap yang juga tertentu, dan yang perlu diperlakukan secara tertentu pula oleh orang-orang di sekitarnya.

Bahkan, berhubung sudah menjadi tradisi tahunan dan bernilai ekonomi, bagi sebagian orang haji menjadi ibadah yang juga bernilai bisnis. Maka menjamurlah birobiro jasa perjalanan haji (dan umrah). Mereka bersaing harga dan fasilitas. Programprogram plus ditawarkan. Demi menarik minat para calon konsumen, para artis dan muballigh pun direkrut menjadi "maskot" untuk menambah nilai jual. Terlepas dari perspektif halal-haramnya dan baik-buruknya, kini haji sudah bertransformasi dari wujudnya yang semula murni sebuah ibadah, menjadi tradisi yang berdimensi sosialekonomi dan bisnis. ${ }^{25}$

Kedua, menjadi diskursus. Setiap agama, yang monoteis maupun politeis, yang tumbuh alami maupun yang berbasis wahyu, lahir pertama kali sebagai sebuah kesadaran ruhani dalam diri pembawanya, rasul di Islam, Yahudi dan Nasrani, atau orang bijak dan semacamnya di agama-agama lain. Nah, ketika kesadaran tersebut disampaikan kepada orang lain, di situlah mulai terjadi diskursus dalam bentuk dialog, konsultasi, kontemplasi hingga debat, tentang keberadaan Sang Wujud Tertinggi

${ }^{24}$ Menurut Agus Sunyoto, penulis buku Atlas Walisongo, gelar "haji" pertama kali muncul pada 1916. Gerakan perlawanan terhadap Belanda sering dipimpin oleh seorang yang pulang berhaji dari Makkah. Gelar tersebut diberikan penjajah Belanda untuk mengidentifikasi orang-orang yang telah berhaji sehingga mudah untuk memantau gerak-gerik mereka. Asal-Usul Gelar "Haji” di Indonesia," http://www.nu.or.id/post/read/54744/asal-usul-gelar-ldquohajirdquo-di-indonesia. Diakses 15 November 2017.

${ }^{25}$ Moeslim Abdurrahman mengkaji secara mendalam tentang fenomena bisnis haji ini dalam disertasinya, On Hajj Tourism: In Search of Piety and Identity in the New Order Indonesia di University of Illinois, Urbana-Champaign, Amerika Serikat, tahun 2000. 
selaku sumber eksistensi kehidupan alam semesta. Diskursus inilah yang juga membangkitkan kesadaran serupa di kalangan para pengikutnya. Apapun dan bagaimana pun the ultimate being ini dikonsepsikan, perbincangan demikianlah yang disebut teologi - dalam maknanya yang jenerik. Dalam makna tersebut, seperti menurut Robert Jackson, teologi berarti diskursus tentang wujud yang diagungkan (to discouse about the divine).

Persoalan terjadi ketika agama tersebut sudah berkembang luas, sementara sang pembawa sudah tiada. Seperti sudah diuraikan di atas, di kalangan mayoritas penganutnya ajaran-ajaran agama tersebut lambat laun menjadi dogma yang ditransfer bukan lagi melalui diskursus, tetapi melalui doktrinasi. Ritual-ritual ibadah juga dilestarikan tanpa diskursus, tapi hanya sekedar pembiasaan dan pembudayaan. Meskipun demikian, di setiap agama tersebut diskursus juga tetap berlangsung, tetapi hanya di kalangan khusus/terbatas - yaitu mereka yang memiliki perhatian besar pada persoalan relijiusitas. Di agama Islam, kalangan terbatas itu misalnya para ulama, cedekiawan, sarjana dan santri. Di tangan merekalah agama Islam bisa bertahan dan lestari.

Di setiap agama, kalangan terbatas inilah yang menjadi pemegang estafet kepemimpinan, tabligh dan pembinaan umat dari sang rasul/penyebar pertama. Kalangan khusus ini, tidak hanya belajar agama secara dogmatis dan tidak pula mengamalkannya sekedar tradisi yang turun-temurun. Akan tetapi, mereka mendialogkannya secara intelektual. Agama tidak sekedar diamalkan tanpa dipelajari, tapi juga dicarikan penjelasannya, didalami maknanya dan dirasakan internalisasinya. Ajaran-agama mereka yakini bukan sebagai dogma tetapi sebagai pencerahan yang argumentatif. Ritual ibadah mereka lakukan bukan sebatas tradisi warisan nenekmoyang, tetapi sebagai pengabdian yang tulus kepada Sang Pencipta. Dengan demikian, Tuhan diposisikan bukan sekedar sebagai objek yang diimani dan disembah saja, tapi juga diperlakukan sebagai "sahabat karib” yang hadir di mana saja mereka berada. Dengan kata lain, selain diimani dan diamalkan, agama juga dijadikan perspektif dalam memahami semua peristiwa kehidupan. Tuhan sebagai the ultimate being, Dia merupakan awal dan akhir segala sesuatu. Tidak ada satu pun fenomena alam semesta yang terwujud tanpa kehadiran peran Tuhan di dalamnya. Itulah yang dimaksud dengan teologi, yakni agama yang bukan sekedar seperangkat dogma yang diimani dan tradisi yang dipatuhi, tapi juga merupakan kesadaran diri (self-conscieussness) terhadap Sang Wujud Tertinggi. ${ }^{26}$ Selama sebuah tradisi relijius masih memiliki gagasan tentang Sang Wujud Tertinggi - kembali mengutip David Tracy - dan selama refleksi intelektual tentang-Nya masih berlangsung, maka di situlah kita temukan hadirnya teologi. ${ }^{27}$

\section{Simpulan}

Akhirnya, dapat disimpulkan bahwa teologi dalam makna jeneriknya sebagai diskurus seputar Wujud Tertinggi tidak memiliki ikatan dalam agama atau kelompok relijius tertentu. Ia adalah ekspresi naluriah manusia, yang lahir dari kesadaran intelektual tentang adanya wujud supranatural di balik setiap fenomena di alam semesta. Penggalian lebih lanjut dari kesadaran relijius ini melalui proses perenungan yang mendalam, menghasilkan konsep-konsep, ajaran-ajaran, serta praktek-praktek

${ }^{26}$ Caird, h. 31.

${ }^{27}$ Jackson, h. 1. 
ritual untuk mengagungkan wujud supranatural tersebut. Di tahap berikutnya, muncullah dua arus besar tradisi relijius yang diikuti umat manusia sepanjang sejarahnya, yaitu politeisme yakni kesimpulan pada adanya sejumlah wujud supranatural pengatur alam semesta, dan monotesime yakni kesimpulan pada adanya wujud supranatural yang maha tunggal. Di antara dua arus besar itu, ada yang berbasis pada diskursus intelektual murni dan ada pula yang berbasis pada kabar suci dari Sang Wujud Tunggal itu sendiri.

Kajian ini tentu masih banyak kekurangannya, namun kiranya bisa menjadi inspirasi untuk riset-riset berikutnya. Di antara bagian yang perlu diselami lebih jauh adalah pelacakan historis tentang perjalanan teologi dari yang semula murni merupakan diskurus filosifis di Yunani, kemudian berevolusi menjadi disiplin ilmu yang mandiri namun bernuansa mistis di tangan peradaban Romawi-Nasrani, Yahudi dan Islam. Namun demikian, dari penelitian ini paling tidak penulis memperoleh gambaran yang lebih terang tentang pola relasi antara teologi dan agama.

\section{Daftar Pustaka}

Abdurrahman, Moeslim, On Hajj Tourism: In Search of Piety and Identity in the New Order Indonesia di University of Illinois, Urbana-Champaign, Amerika Serikat, tahun 2000.

Agus, Burhanuddin, Agama Dalam Kehidupan Manusia, Pengantar Anthropologi Agama (Jakarta: Rajawali Press, 2006)

Blackburn, Simon, the Oxford Dictionary of Philosophy (Oxford: Oxford University Press, 1996).

Caird, Edward, the Evolution of Theology in the Greek Philosophers: Vol. 1 (Oregon: Wift \& Stock Publishers, 2015).

Hooker, Richard, Of the Laws of Ecclesiastical Polity

Jackson, Roger R., Buddhist Theology: Critical Reflections by Contemporary Buddhist Scholars (Surrey: Curzon Press, 2000).

Largen, Kristin Johnston, Finding God among Our Neighbors: An Interfaith Systematic Theology (Fortress Press,U.S., 2017)

M.D, James Weir, Jr., Religion and Lust or The Psychical Correlation of Religious Emmotion and Sexual Desire: Thrid Edition (Chicago: Chicago Medical Book Co., 1905)

Narayana, Laksmi dan Rama Putra Iswara, Mendebat Agama Langit: Membunuh Dikotomi Ngawur Agama Langit-Agama Bumi (Yogyakarta: Narayana Mmrti Press, 2017).

Pusat Bahasa Pendidikan Nasional, Kamus Bahasa Indonesia (Pusat Bahasa: Jakarta, 2008).

Stiftung, Karl-und-Gertrud-Abel, Ideal and Culture of Knowledge in Plato (Frankfurt: Franz Steiner Verlag Stuttgart, 2003).

Suyûț̂ি Abdurrahnmân as-, Syarrh as-Suyûț̂ li Sunan an-Nasâ̂̃: Juz 3 (Halab:Maktabah alMațû́'ât al-Islâmiyyah, 1986)

Artikel Online:

"Asal-Usul Gelar "Haji” di Indonesia," http://www.nu.or.id/post/read/54744/asalusul-gelar-ldquohajirdquo-di-indonesia. Diakses 15 November 2017.

https://www.merriam-webster.com/dictionary/theology;

https://en.oxforddictionaries.com/definition/theology, diakses pada 26 September 2017, pukul 09.05 
https://en.oxforddictionaries.com/definition/theology, diakses 31 Juli 2017, pukul. 14.05 . 